\title{
The Formative Years of the Modern Corporation: The Dutch East India Company VOC, 1602-1623
}

\author{
OSCAR GELDERBLOM, ABE DE JONG, \\ AND JOOST JONKER
}

With their legal personhood, permanent capital, transferable shares, separation of ownership and management, and limited liability, the Dutch and English colonial trading companies VOC and EIC are considered institutional breakthroughs. We analyze the VOC's business operations and financial policy and show that its novel corporate form owed less to foresight than to piecemeal engineering to remedy design flaws. The crucial feature of managerial limited liability was not, as previously thought, integral to that design, but emerged only after protracted experiments with various solutions to the company's financial bottlenecks. Legal form followed economic function, not the other way around.

$\mathrm{T}$ he intercontinental trading companies set up by the British and Dutch at the turn of the seventeenth century are generally considered key institutional innovations because of their corporate form (North 1990). The English East India Company (EIC), founded in 1600, and the Dutch East India Company (VOC), founded in 1602, pioneered features which later became textbook characteristics of modern corporations: a permanent capital, legal personhood, separation of ownership and management, limited liability for shareholders and

The Journal of Economic History, Vol. 73, No. 4 (December 2013). C The Economic History Association. All rights reserved. doi: 10.1017/S0022050713000879.

Oscar Gelderblom is Associate Professor of Social and Economic History, Utrecht University, Drift 6, 3512 BS Utrecht, The Netherlands. E-mail: o.gelderblom@uu.nl. Abe de Jong is Professor of Finance, Rotterdam School of Management, PO Box 1738, 3000 DR Rotterdam, The Netherlands; and Professor of Financial Accounting, University of Groningen, PO Box 72, 9700 AB, Groningen, The Netherlands. E-mail: ajong@rsm.nl. Joost Jonker is NEHA Professor of Business History, University of Amsterdam, Faculty of Humanities, Capaciteitsgroep Geschiedenis, Spuistraat 134, 1012 VB Amsterdam, The Netherlands; and Associate Professor of Social and Economic History, Utrecht University. Drift 6, 3512 BS Utrecht, The Netherlands. E-mail: j.jonker@uu.nl.

The authors thank participants of the Financial History Workshop in Antwerp (May 2012), the conference, "The History of Business and Finance," Institute for Advanced Study in Toulouse (April 2012); the Low Countries History and The Economic and Social History of the Pre-Modern World, 1500-1800 Seminar, London (January 2012), the Economic History Society meeting (April 2011) the Economic History seminar of Universidad Pompeu Fabre (Barcelona, April 2011), finance seminar at University of Glasgow, the seminar of the Helsinki Finance Group, Paul Rhode, and two anonymous referees, for helpful comments on earlier versions of this article, and Karen Hollewand for research assistance. Funding: Research for this article was funded by the European Science Foundation (EURYI grant), the Netherlands Organisation of Scientific Research (VIDI grant), and the Rotterdam School of Management. 
for directors, and tradable shares (Hansmann and Kraakman 2004). The success of these trading companies in spearheading European colonization is generally associated with the competitive edge lent by their particular corporate form, which in turn counts as an example of the superiority of Western legal traditions over those in China or the Islamic world (Kuran 2010a, 2010b).

The new corporate features are usually seen as purposeful adaptations of existing legal forms to the challenges of Europe's overseas trade with Asia, notably the large amounts of capital required, the long duration of voyages, and the increased risks along the way (Hansmann and Kraakman 2000; Hansmann, Kraakman, and Squire 2006). They are also regarded as closely related to each other, a logical set making up a winning formula. This interpretation rests heavily on work by legal scholars seeking to unearth the roots of concepts such as limited liability and legal personhood (Van der Heijden 1908; Van Brakel 1908; Frentrop 2003; Den Heijer 2005; Harris 2000, 2010). However, there are two major problems. First, for a long time the dominant British and Dutch companies faced identical challenges, but differed in the legal solutions adopted (Steensgaard 1973, 1982). By the early 1620s the VOC possessed transferable shares, a permanent capital, and limited liability for owners and managers, whereas the EIC introduced similar features only during the 1650s (Gelderblom and Jonker 2004; Gelderblom, De Jong, and Jonker 2011; Harris 2000). Second, while England's lag may relate to political factors, notably the lack of limited government (Harris 2010; Dari Mattiacci et al. 2012), the time it took for the VOC to assemble various features shows that they did not form a coherent logical set from the start, but instead emerged one-by-one in response to the growing financial strains of its Asian operations. The company had transferable shares and limited liability for shareholders from the outset, but obtained a permanent capital only in 1612 and limited liability for its directors in 1623.

We analyze the VOC's business operations and notably the financial policy during its first two decades to show how the company's corporate features were shaped by severe cash constraints resulting from its military and commercial operations. For this purpose, we have constructed new estimates of income and expenditure for the full period from the scarce available accounts combined with shipping data. ${ }^{1}$ Fragmentary account data survive for only three of the VOC's six chambers: Amsterdam, Zeeland, and Enkhuizen. Since, according to the

\footnotetext{
${ }^{1}$ De Vries and Van der Woude (1997, pp. 382-96) combined the VOC's shipping statistics (Bruijn, Gaastra, and Schöffer, 1979-1989) with sales revenues to estimate turnover and gross profit margins per decade, not per year. Cf. also De Vries (2003, pp. 82-91).
} 
charter, each chamber had a fixed share in the company's operations, we can extrapolate the costs and revenues of one chamber into figures for the company as a whole, filling in the gaps between data with what we know of shipping operations from the detailed records compiled by Bruijn, Gaastra, and Schöffer (1979-1987).

This enables us to pinpoint a single cause, financial constraints originating in governance flaws in the VOC's original design, for its known teething troubles. ${ }^{2}$ Directors remedied the flaws in a process of piecemeal engineering, creating both stopgaps and more lasting solutions which by the early 1620 s had hardened into the corporate form as we know it. Therefore that form owed more to a sequence of actions to relieve the friction between the company's governance, specific operational demands, and the available finance options, than to the logic of any legal system, contractual form, or set of forms.

The argument runs as follows. Section 1 analyzes the VOC's failure to emulate the commercial success its predecessor companies enjoyed before 1602. Low sales revenues and sharply rising costs confronted the directors with the impossibility of keeping to the original intention of relying on circulating capital for finance and of winding up the company in 1612. Consequently, from 1609 the central board or Heren XVII strove to obtain a permanent capital, which they only got at the penalty of increasing the company's cash constraints and eliminating the option of raising more equity (Section 2). We demonstrate in section 3, which relates to 1612-1617, how that penalty forced the company to rely on circulating capital as its main source of finance, topped up with all kinds of expedients. Finally section 4 details how the VOC's formative years ended. In 1617 the directors tackled one of the charter's flaws by mutually guaranteeing the debts contracted by their respective chambers, thereby gaining access to crucial additional resources. When investors started questioning the status of bonds sold by other chambers in the main money market, Amsterdam, directors unilaterally rejected their personal liability for company debt in 1623 . The conclusion explores the implications of these findings for our understanding how and why modern corporate features emerged.

\footnotetext{
${ }^{2}$ Cornelis de Heer (1929, pp. 5-18) identified the financial problems related to the decentralized governance structure of the company, without connecting them to the organizational changes of the first two decades. Niels Steensgaard (1973, pp. 126-40; 1982) documented the piecemeal engineering of the corporate form, but overlooked the financial constraints shaping this process, as does Frentrop (2003, pp. 49-104) in his analysis of the lacunae in the 1602 charter and shareholder pressure to change the company's governance structure.
} 


\section{CONTINUING AS BEFORE}

In 1595 a company of Amsterdam merchants equipped a fleet of four ships under the command of Cornelis de Houtman to sail to Asia. Upon De Houtman's return in 1597, sales revenues barely covered the costs of the expedition, but its successful completion was sufficient proof for investors that the fledgling Dutch Republic stood a real chance to replace Portugal as the principal supplier of spices to Europe. A flurry of new expeditions followed in Amsterdam, Middelburg, and Rotterdam, totaling 16 fleets worth close to 8 million guilders between 1598 and 1602 (see the Online Appendix). These so-called voorcompagnieën or early companies were organized as a special-purpose partnership, which limited investors' liability to the specific purpose and duration of the venture (Gelderblom, De Jong, and Jonker 2011). Shareholders paid cash up front so as to allow the small group of managing shareholders to equip ships, hire crews, and purchase trade goods and especially silver to buy spices in Asia. ${ }^{3}$ Upon the ships' return, directors sold the cargo and other company assets, collected their fees, and distributed the remainder among shareholders. The shareholders could then decide whether or not to reinvest in a subsequent expedition organized by the same directors (Gelderblom 2003, pp. 625-26). Even if most investors left it to the directors to act on their behalf, it was wellunderstood that directors were not liable for the shareholders which they had brought into the company, for instance when one of them failed to pay up a promised share. ${ }^{4}$ Conversely, the shareholders could not be held liable for any debts that the directors incurred while preparing the fleet (Gelderblom, De Jong, and Jonker 2011, pp. 36-37). When the directors borrowed money, for instance to buy ships or silver, or to advance wages, they did so on their own credit and were liable accordingly. The creditor risk of such credit was limited, however. Shareholders paid cash up front before the fleets departed, so all debts could be extinguished at the same time.

Initially funding voyages back-to-back like this worked well enough for all concerned. The early companies yielded high returns, so organizers had little difficulty in persuading investors to roll over stakes

\footnotetext{
${ }^{3}$ Cf. the cash payments to directors and the sales returns rolled over by the Amsterdam merchants Augustijn Boel and Hans Thijs who invested in eight expeditions from Amsterdam between 1598 and 1602: Bibliotheca Thysiana, Grootboek B, Hans Thijs (1598-1603), fol. 28, $88,108,150,200$. Cf. also the subscriptions to Amsterdam's Oude Compagnie: NA 1.04.01 Inv. $\mathrm{Nr} 27$, Inv. Nr 28, fol. 14-15; fol. 45v Inv. Nr 31.

${ }^{4} \mathrm{Cf}$. the resolution to this effect taken by the directors of Amsterdam's Oude Compagnie: NA 1.04.01 Inv. Nr. 27, fol. 45v (30 December 1600).
} 
from one venture into the next. Moreover, investors who needed money had the option of selling their stake as a straightforward claim to a proportional share of an expedition's profits (Gelderblom and Jonker 2004). Mounting competition, however, initiated a process of corporate consolidation in which the balance between directors, company, and investors shifted decisively. The rivalry between various Dutch companies weakened their overall position in the Asian trade, and in 1600 Britain also entered the fray, London merchants investing the equivalent of 600,000 guilders in their first attempt to fetch spices directly from Asia (Scott 1913, II, pp. 91-113; Chaudhuri 1965, pp. 207-23). Amsterdam merchants responded by merging their two companies in 1601 and putting 1.3 million guilders into a fleet of eight ships (Gelderblom and Jonker 2004). It took another year of arduous negotiations under the auspices of the Estates General to convince the sponsors of companies elsewhere. Notably Zeeland merchants who resented Amsterdam's growing commercial dominance (Enthoven 1996; Lesger 2006) resisted the amalgamation of all Asian ventures. The company which emerged in March 1602 was a compromise between the various interests concerned. Its operations were split over six participating cities, each with a fixed share, while the Estates General retained a say in every important operational decision (Gelderblom, De Jong, and Jonker 2011).

The VOC charter created a large concern with 6.4 million guilders' capital, but the financial organization of the business did not really change. Whereas the charter and trade monopoly bestowed by the Estates General were to run 21 years, the new company itself was conceived as a succession of separate, overlapping expeditions, the returns of one financing the next. After ten years, the entire concern was to be liquidated and the capital returned to shareholders, unless they chose to reinvest in a successor company set up to exploit the second half of the monopoly. Subscribers to the first account paid up in four installments. The first three were large enough to equip a fleet, but the fourth and smallest one in the autumn of 1606 amounted to no more than 8.3 percent of capital. The company's founders clearly expected that by then enough ships would have come back from the first expedition to finance the fourth.

This back-to-back financing shows that the VOC capital was not considered as money set aside to finance the fixed assets needed, but as circulating capital, a revolving fund to be replenished from sales revenues. The scope for fixed investments was thus limited to the money remaining after the equipment of subsequent fleets. In a large consolidated company this should not have mattered, but then the 
early VOC was no such thing because the merger had stopped short of full consolidation. The central board or Heren XVII laid down policy, prices, terms, and conditions, while the directors of the company's six chambers (kamers) remained responsible for running their share of the joint operations from their respective ports: equipping ships, recruiting labor, selling produce, and paying bills. Consequently, an individual chamber's cash flow, and by extension its participation in expeditions, depended largely on the success of preceding expeditions.

The boundaries of the revolving finance system become clear when we examine the VOC's first expeditions a little closer. The company kept up a regular flow of 10-12 ships on each of its first three expeditions between December 1603 and April 1606 for a total of 32 . The biggest chamber, Amsterdam, provided the bulk with 19 vessels (See the Online Appendix). The size of these expeditions was determined by the flow of installments coming in, with the amount of silver sent out to pay for purchases figuring as a balancing item. Even so the preparations for a new expedition started some time before shareholders would pay. The company charter had made a provision to cover early expenses by awarding shareholders paying early an 8 percent interest until the fleet sailed. ${ }^{5}$ Since the Amsterdam Chamber could borrow for 7 percent or less on the local money market, directors preferred that to calling subscriptions early, so they borrowed up to 400,000 guilders between January 1604 and April 1605 to prepare the second fleet (Figure 1). From July 1605 they borrowed again ahead of installments coming in, repaying most of the money six months later, either from the installments due in October 1605, or from sales revenues. ${ }^{6}$ In April 1605 its ship Hof van Holland had returned to port after an exceptionally swift round trip of only 476 days, and sales from its cargo may have helped to extinguish debt. During 1606 four more ships arrived back, enabling directors to pay off most of their debts.

If the revolving finance system worked for Amsterdam, the other chambers had a tough time of it. The second biggest chamber, Zeeland with a 25 percent stake in operations, participated with two to three ships in each of the initial three expeditions, but its first ship returned only in October 1606, followed by a second ship eight months later. Though Zeeland immediately started selling products, this had generated no more than 650,000 guilders by July 1608 (See the Online Appendix). Meanwhile the four other, much smaller, chambers

\footnotetext{
${ }^{5}$ Den Heijer (2005), p. 61; NA. 1.04.02 VOC, Inv. No. 7162, carta 72-302.

${ }^{6}$ The Amsterdam Chamber spent less money on the third fleet than the amount it received from the third installment: De Korte (1984, p. 10).
} 


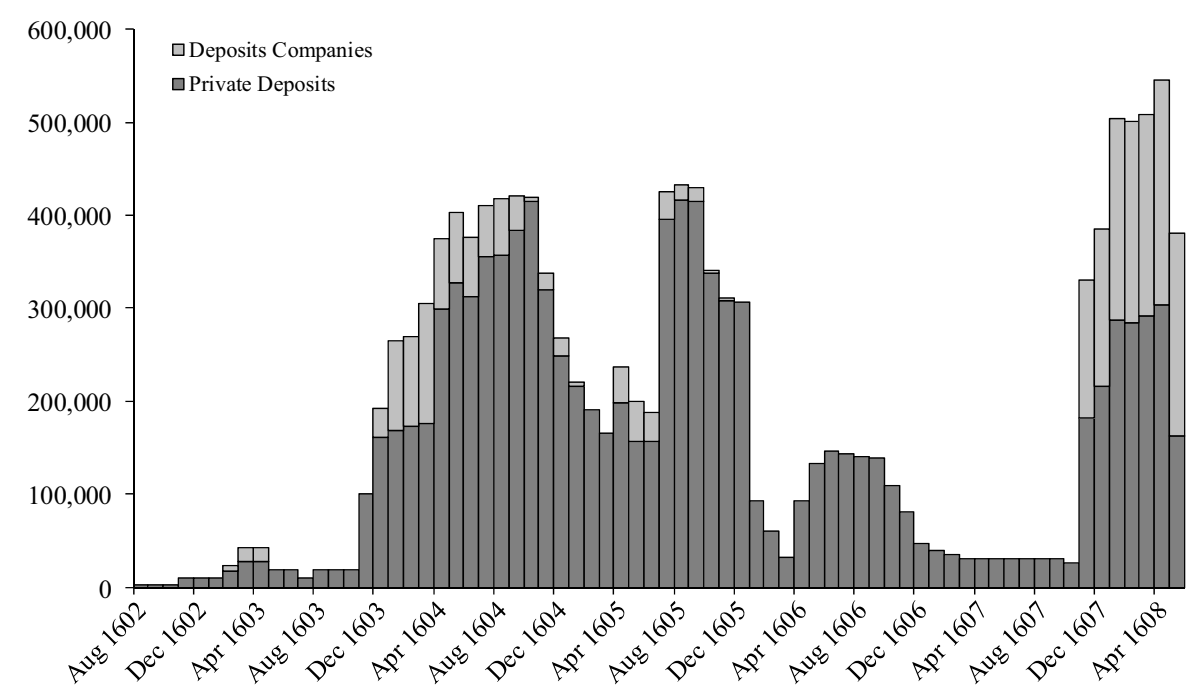

FIGURE 1

DEBT RAISED BY DIRECTORS OF THE AMSTERDAM CHAMBER OF THE VOC, AUGUST 1602-MAY 1608

could only muster sufficient resources for participating in alternate expeditions. The Chambers of Enkhuizen and Hoorn joined the first expedition with two ships each, skipped the second one, and then joined the third with one each. Delft and Rotterdam passed up on the first expedition, joined the second, and skipped the third. Out of these four, only Hoorn had received any products to sell, and thus money to reinvest, from its previous expedition. Both Rotterdam and Enkhuizen had lost ships, and Delft welcomed back its first vessel only in 1608.

Return cargoes also remained small relative to the VOC's capital and to what the early companies had managed to do because directors needed to spend substantial resources on warfare. Their main principal, the Estates General, insisted on military operations to deflect Spain's attention and forces from the Dutch Republic itself, while the competition overseas had also started a vicious spiral of violence there (Blussé and Winius 1986). The scale of the VOC's military efforts encountered serious board opposition. In 1603 and 1605 two prominent directors, from Zeeland and Amsterdam, respectively, resigned in disgust over the costs of warfare (Gelderblom, De Jong, and Jonker 2011, p. 47). The Zeeland Chamber successfully claimed a priority right to at least one return cargo every year, but the company continued sending over soldiers, investing in hardware 


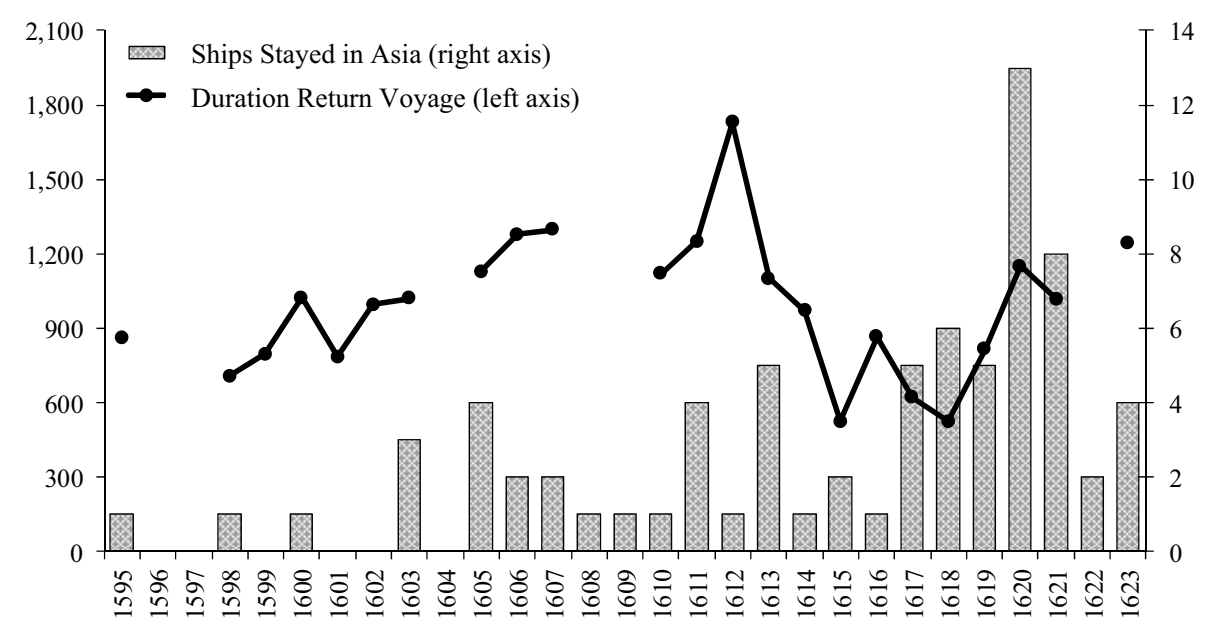

FIGURE 2

AVERAGE DURATION (IN DAYS) OF RETURN VOYAGES TO ASIA AND THE NUMBER OF SHIPS THAT STAYED THERE, PER YEAR OF DEPARTURE FROM DUTCH REPUBLIC

Source: Bruijn, Gaastra, and Schöffer (1987); the calculated duration does not include the ships remaining in Asia.

such as forts and cannon, and building up an Asian fleet. Nine ships of the first three fleets stayed there, and the directors supplemented this force by extending the tour of duty for other ships leaving the Dutch Republic to an average of 1,200 days, more than three years (Figure 2). ${ }^{7}$

Extending tours of duty forced chambers to wait longer for return cargoes, pushed up cost, and drained the chambers' cash flow. More of the silver sent out to Asia had to be used locally for buying food and paying wages. At home, back pay due to crews sent out mounted and had to be paid out immediately when ships finally returned. Between December 1606 and July 1608 the Zeeland Chamber alone paid 130,000 guilders in costs over returning ships in back pay, storage, and directors' fees (Table 1). ${ }^{8}$ The returning ships were totally worn out, and reequipping them cost nearly as much as buying new, but the VOC had not budgeted for such a rapid depreciation rate.

\footnotetext{
${ }^{7}$ Cf. also Parthesius (2010) on the size of the Asian fleet in the first half of the seventeenth century.

${ }^{8}$ As early as 1608 the VOC operated an ingenious system enabling its employees to assign part of their pay to relatives, thereby at the same time smoothing the back pay liabilities problem: NA 1.0.02 VOC, Inv. No. 221, Resolutions Heren XVII, 4 August 1608.
} 
TABLE 1

VOC ZEELAND, BILLS PAID FOR RETURNED SHIPS, DECEMBER 1606-JULY 1611

\begin{tabular}{lrrrr}
\hline \hline Period & Wages & Other Costs & Commission & Total \\
\hline Dec. 1606 - Jul. 1608 & 137,053 & 22,267 & 32,540 & 191,860 \\
Aug. 1608 - Feb. 1609 & 14,396 & 9,425 & 0 & 23,821 \\
Mar. 1609 - Aug. 1609 & 39,406 & 1,700 & 17,862 & 58,968 \\
Sept. 1609 - Feb 1610 & 42,513 & 4,783 & 0 & 47,296 \\
Mar. 1610 - Aug. 1610 & 34,744 & 9,616 & 0 & 44,360 \\
Sept. 1610 - Jul. 1611 & 24,492 & 44,126 & 0 & 68,618 \\
Total & 292,604 & 91,917 & 50,402 & 434,923 \\
\hline
\end{tabular}

Source: NA 1.04.02 VOC, Inv. No. 11349, carta 61, 62, 75, 97, 119-120, 137-139.

The burden of these commitments weighed all the heavier in the face of low sales revenues. During the VOC's first years, spice sales in the Dutch Republic drew largely on stocks from the early companies, including the 1602 expedition of fourteen ships under Wybrant van Warwijck whose management VOC directors had taken over.'

Consequently, the board did not have to worry about the Republic's position as leading market for Asian spices, though at the cost of severely limiting the VOC's own sales volume. This led to a crunch in 1606 , when the VOC needed money to equip a fourth fleet with sufficient men and arms to bolster its overseas position and conduct the ongoing negotiations with Spain from strength. Gathering that money took time, so the sailing of the fourth fleet was postponed to December 1607, but even that was insufficient. The Zeeland Chamber, based in Middelburg, could muster its share in the expedition only by obtaining a subsidy from the Zeeland Estates and Enkhuizen decided not to take part at all. ${ }^{10}$ Rotterdam and Delft, which like Enkhuizen were still waiting for their first ship to return, probably obtained funds through Amsterdam to finance their participation of one ship each in the 1607 expedition. The Amsterdam Chamber itself had to stretch its

\footnotetext{
${ }^{9} \mathrm{Cf}$. for Zeeland's sales of spices from the fourteen ships: NA 1.04.02 VOC, Inv. No. 11349 Copieboeck van diversche Rekeningen, carta 21, 39, 50, 77, 82, 122-125, 127. Dividends from Amsterdam's six ships in the 1602 fleet paid to the Amsterdam investor Hans Thijs suggest that by November 1607 sales from these ships already amounted to 870,000 guilders (University Library Leiden, Biblioteca Thysiana, Ledgers Hans Thijs 1604-1610; Gelderblom and Jonker 2004). In addition to spices purchased in Asia, the fleet of Warwijck also captured the Portuguese carrack Santa Catharina, a prize worth 3.4 million guilders: Van Dam (1927, vol. 1.2, p. 485).

${ }^{10}$ NA 1.04.02 VOC, Inv. No. 11046, Resolution of the Zeeland Estates, 11 September 1606, granting a subsidy of 300,000 guilders to the VOC, funded with customs revenues and payable over the course of three years, "to build fortications and establish and maintain a garrison in East India."
} 
resources, with its short-term debt rising with another 500,000 guilders during the first half of 1608 (Figure 1). The money may have been used to cover the costs of returning ships, but Amsterdam had also started to relieve the cash constraints of other chambers by allowing them to run substantial overdrafts on their current account. ${ }^{11}$

These internal credit lines required changing the VOC's governance by introducing uniform accounting standards and procedures as well as regular inspections to inspire the necessary mutual confidence. Chambers took turns in pairs to inspect each other's accounts and all chambers had to submit statements of revenues and expenses to each meeting of the central board. ${ }^{12}$ By providing a firm basis for easing the cash flow constraints of individual chambers, this accounting harmonization signaled a marked step forward, but it failed to improve the VOC's overall cash position. The maturity mismatch between short-term debts and longer voyages remained, creating liquidity risk (Diamond 1991), and forcing the company to reduce its operations. During 1608 and 1609 only three small ships were sent to Asia and it took until January 1610 before the VOC could again muster a full expedition of nine ships.

\section{PAYING FOR PERMANENCE}

The financial structure created in 1602 put an effective limit on the scale of the VOC's military operations. With circulating capital, the company could only afford intermittent campaigns, so it repeatedly lost positions built up on Malaka and on the Molucas (Blussé and Winius 1986, pp. 77, 80; Witteveen 2011, pp. 65-66, 69). This put the VOC in a quandary. To sustain its position, the VOC needed to expand military operations, which it could not without first raising sales revenues. But doing that would temporarily weaken military efforts, because money spent on trade could not also buy ships and soldiers.

\footnotetext{
${ }^{11}$ For instance, in July 1610 Middelburg's cash outflows exceeded inflows by 500,000 guilders. Eighty percent of this shortfall was covered by an overdraft on the current account with Amsterdam of 400,000 guilders (NA 1.04.02 VOC, Inv. No. 11349, Copieboek rekeningen Zeeland, carta 74). Loans between chambers were coordinated in the meetings of the Heren XVII: Van Dam (1927, vol. 1, p. 233); De Heer (1929, pp. 12-13, 26-27).

${ }^{12}$ On May 26th, 1606 the company directors decided that chambers would inspect each other's accounts (NA 1.04.02 VOC, Inv. No. 221, fol. 66). On August 4th, 1608 the Heren XVII resolved that the chambers had to send each other monthly reports: NA 1.04.02 VOC, Inv. No. 221, fol. 253.
} 
TABLE 2

THE ESTIMATED ANNUAL COST OF THE VOC'S MILITARY EFFORT IN ASIA, 1609

\begin{tabular}{lr}
\hline \hline Expenses & Amount \\
\hline Soldiers & 120,000 \\
Sailors & 90,000 \\
Provisions & 100,000 \\
Fortifications & 50,000 \\
Depreciation & 60,000 \\
Total & 420,000 \\
\hline
\end{tabular}

Source: Van Dam (1927, vol. 1.2, pp. 525-26).

This critical check was diagnosed as early as 1608, when the commander of the second fleet, Cornelis Matelieff de Jonge, returned to the Republic. He sounded the alarm in a series of memos to the company directors, the Estates General, and to prominent public figures such as Hugo Grotius and Johan van Oldenbarnevelt. ${ }^{13}$ According to Matelieff, the VOC had wrongly attempted to combine warfare with business, and therefore failed to succeed at either. The situation demanded a determined push which the admirals of successive fleets had not been able to give. Matelieff recommended that the company put its operations on a more permanent footing by establishing a central hub such as the Portuguese possessed in Malaya, and by appointing a governor-general there to take charge. Only then could the VOC hope to gain a firm grip on spice supplies. The former commander recognized that this policy change required heavy investment, but considered this necessary to realize the VOC's military and commercial aims (Van Rees 1868; Gaastra 1985; Rietbergen 1987; Witteveen 2011).

However, the company's finances left no room for long-term investments in military spending. In 1609 the VOC's annual war costs amounted to more than 400,000 guilders in wages, food, maintenance, and depreciation (Table 2). So far, sales had yielded barely enough to cover these expenses, let alone expand the military effort. Moreover, with the VOC's statutory liquidation only three years away, large investments would seriously reduce the chances of launching a successor company (Dari Mattiacci et al. 2012). Matelieff understood that the statutory liquidation threatened the entire venture with extinction. Current shareholders would not reinvest in another venture with high costs and low returns if, as seemed likely, operations were to prove of little or no value by 1612 . Prospective investors had no incentive to participate in a successor company if the old one had failed to pay dividends or establish a firm position overseas.

\footnotetext{
${ }^{13}$ Matelieff de Jonge to Van Oldenbarnevelt, 18 mei 1609 (Veenendaal 1962, pp. 319-27); Matelieff de Jonge to Grotius, 31 August 1610, Correspondence Hugo Grotius, 198A, pp. 71-75.
} 
Matelieff came to the logical conclusion and recommended to the Estates General that the statutory liquidation be ignored so as to turn the VOC into a permanent concern (Steensgaard 1982; Witteveen 2011).

Matelieff's proposal did not remain secret; in May 1609 Isaac Lemaire angrily mentioned it to Grand Pensionary Johan van Oldenbarnevelt. Ignoring the statutory liquidation would be illegal, improper, and unfair to shareholders, Lemaire argued. He warned that without dividends, full accounts, and liquidation, no investor would subscribe to a successor (Frentrop 2003, pp. 69-75; Shareholder Rights 2009). On the basis of his subsequent bear raid on the VOC shares (Van Dillen 1930) and his advances to the French king to organize a competing company (Murphy 1972, pp. 20-30), Lemaire earned his reputation as a rancorous renegade. Nevertheless, his petition was a fair argument about a point of law and his justified complaint about the company's failure to pay dividends must have reflected a wider dissatisfaction (Frentrop 2003; Gelderblom, De Jong, and Jonker 2011). The VOC directors responded by posting dividends, clearly in the hope of appeasing shareholders and thereby smoothing political opposition against Matelieff's proposal. During 1610 and 1612 the VOC awarded dividends totaling 162.5 percent, or 10.4 million guilders, an amount clearly meant as a payoff to shareholders. This represented full reimbursement plus ten times the going interest rate of 6.25 percent for each year their capital had been tied up in the company (Steensgaard 1982; Gelderblom, De Jong, and Jonker 2011). The board could now claim that it had fulfilled a key part of their charter obligations.

This was a risky gambit because the VOC lacked the cash to pay dividends, but the directors probably expected sales to pick up. The early companies' stocks were dwindling and the Twelve Years' Truce with Spain (1609-1621) opened markets in the Spanish Netherlands and southern Europe. Moreover, the first dividend was announced just after four heavily laden ships had arrived back during the summer of 1610 . However, even rapidly rising sales revenues would be insufficient to equip new fleets and pay the dividend, so the VOC offered the dividend largely in kind using the company's own official prices as conversion measure. In August and September shareholders were awarded an initial 125 percent in mace or money followed by another 7.5 percent in money during September. ${ }^{14}$

\footnotetext{
${ }^{14}$ NA 1.11.01.01 Aanwinsten Eerste Afdeling, Inv. No. 626 (1893, 29b), Resolutions of the Heren XVII, 30 August 1610 (75 percent), 15 September 1610 (50 percent), and 16 September 1610 (7.5 percent).
} 
TABLE 3

DIVIDENDS IN KIND PAID TO THE SHAREHOLDERS OF THE ZEELAND CHAMBER, $1609-1612$

\begin{tabular}{lrrrr}
\hline \hline Period & Pepper & Mace & Nutmeg & \multicolumn{1}{c}{ Total } \\
\hline Mar 1609 - Aug 1609 & 19,647 & 0 & 0 & 19,647 \\
Sep 1609 - Feb 1610 & 63,532 & 0 & 0 & 63,532 \\
Mar 1610 - Aug 1610 & 1,630 & 0 & 0 & 1,630 \\
Sep 1610 - Jul 1611 & 115,386 & 10,213 & 0 & 125,598 \\
Aug 1611 - Jul 1612 & 94,996 & 43,606 & 116,072 & 254,674 \\
Sep 1612* - Nov 1612 & 0 & 0 & 36,133 & 36,133 \\
Total & 295,191 & 53,818 & 152,205 & 501,214 \\
\hline
\end{tabular}

Source: NA 1.04.02 VOC, Inv. No. 11349, Copieboek rekeningen Zeeland; *the account books were closed on July 31 st and only reopened on September 4th, upon the directors' return from a general board meeting in Amsterdam (carta 119-120, 137-139).

If directors had hoped that shareholders would accept the payments in kind, they were mistaken, as dividend payments recorded by the Zeeland Chamber show (Table 3). The directors in Middelburg had anticipated on the dividends during 1609, selling shareholders small quantities of spices, with one-quarter of their value being discounted against future dividends. Three years later, in November 1612, the chamber had still only paid out 0.5 million guilders, 38.5 percent of equity, as dividend in kind. If we take this ratio as representative for the company as a whole, dividends in kind amounted to no more than 2.5 million guilders until the end of 1612 , i.e., barely a quarter of the total. $^{15}$

The shareholders' refusal to accept dividends in kind left the company with a substantial liability at a time when it needed all its money for operations in Asia. Though the 1609 truce with Spain appeared to ease the pressure of warfare overseas, the company could not afford to drop its guard. Under the terms of the truce, a resumption of hostilities in Asia would not necessarily have repercussions for the situation in Europe and news about a military build-up in the Philippines raised the specter of a Spanish offensive. Moreover, foreign competitors saw their chance to obtain a larger share of the spice trade, and although the French managed to send a few ships only (Du Fresne de Francheville 1738; Warnsinck 1943, p. xxvii), England's East India Company invested the equivalent of no less than 3.4 million guilders in seven voyages between 1609 and 1612 (Chaudhuri 1965, pp. 207-23). The VOC had to try and keep up, resulting in an estimated 2.4 million

\footnotetext{
${ }^{15}$ In November 1613 the company directors reported to the Estates General that up to then the VOC had paid 57.5 percent in cash and only 'some spices to some shareholders' ("eenige specerijen aen sommigen uuijtgedeelt"): NA 1.04.02 VOC, Inv. No. 368, 22 November 1613.
} 
guilders spent on 14 ships in three smaller fleets sailing between January 1610 and 1611, and another 2.6 million guilders on 16 ships between 1611 and 1612 (cf. Online Appendix).

These investments tested the financial limits of several chambers. The directors tried to offload some of their costs on the Estates General by petitioning for a subsidy, claiming that a commercial company ought not to bear costs incurred for the country's military interests, but they had limited success. ${ }^{16}$ Between 1609 and 1612 the Estates General awarded subsidies of only 390,000 guilders in tax relief plus some material assistance in the form of ships and ordnance (De Jong 2005, p. 116). The company therefore had to finance the expeditions primarily from money raised by the selling of goods brought ashore during 1610 and 1611. To speed up revenues the chambers offered buyers rebates, i.e., discounts on a given sale's price for cash up front rather than after the customary nine months' term (Schalk 2010).

The discounts generally translated into an annualized interest rate of slightly over 10 percent, which was high compared to market rates, but rebates offered the advantage of not weighing on the directors' credit and liability for company debt. Charter Clause 47 exempted the directors from liability for specific debts, such as wage arrears. In line with the literature we have until now interpreted this clause as meaning to exempt them from liability for all debts (Gelderblom, De Jong and Jonker 2011). New material has made us change our view. Surviving VOC bonds show that directors contracted debt for their personal account, pledging their person and goods in the accustomed way of such bonds. ${ }^{17}$ Moreover, we possess clear indications that outsiders did indeed hold them personally liable for these debts. When in 1611 the Middelburg Chamber had postponed paying import duties for so long that the Zeeland Estates' patience had run out, officials did not sequester the chamber's possessions, the logical course of action if Clause 47 had given directors full limited liability. Instead, the Estates threatened them with imprisonment for debt. ${ }^{18}$ From this we conclude that the directors bore personal liability for company debt, which constrained the VOC's borrowing.

\footnotetext{
${ }^{16}$ NA 1.01.03 Staten Generaal, Inv. No. 4841, fol. 89v, resolution 8 September 1609; fol. $100-107 \mathrm{v}$, petition, $16 / 17$ November 1610 . On earlier proposals for state subsidies drafted by Hugo Grotius in 1605 and 1606, see Van Ittersum (2006, pp. 177-86).

${ }^{17}$ Three such bonds in NA 1.04.02 VOC, Inv. No. 7064 (insurance contract), Film No. 4883, one bond from December 1621 and two from January 1622.

${ }^{18}$ NA 1.04.02 VOC, Inv. No. 11046, resolutions Estates Zeeland concerning the VOC, 1607-1700, 9 May, 8 June, 20 and 22 September 1611. The resolutions do not mention what happened, so the two sides probably settled.
} 
The VOC's precarious finances would have discouraged them to increase their exposure. In July 1612 the Estates General formally allowed the company to ignore the statutory liquidation due that year. To appease shareholders directors gave them the still unpaid 7.5 percent in cash promised back in 1610, and then offered those who had refused to accept spices a payment of 50 percent in cash on condition that the remainder of their dividend would be paid later, 42.5 percent in cash in 1613 and 62.5 percent in cash or nutmeg in $1616 .{ }^{19}$ In other words, the cash required to pay reluctant shareholders their due was such a strain that payment had to be stretched out over several years, effectively forcing them to reinvest their earnings for a period of uncertain duration. Moreover, the unilateral decision to ignore liquidation barred the company from raising more equity, because that would require renegotiating the charter and running the risk of snubbed investors demanding firm guarantees that its clauses would be honored in the future.

Permanence thus came at the high price of further financial strains. The dividends promised but not paid to shareholders precluded raising new equity at a time when international competition was growing. Nor could the company suspend using force in the Indonesian archipelago without making its trading posts an easy prey for the Portuguese, English, and even the budding French competition. Moreover, the VOC failed to capture established objectives such as the conquest of the Banda Islands and a firm position on Java (Gaastra 1991 , pp. 40, 45). One way or another more capital would have to be found if the company was to retain its leading role in the import of Asian spices to Europe.

\section{ESTABLISHING AN OPERATIONAL HUB}

Our reconstruction of sales revenues and equipment costs, summarized in Figure 3, highlights how the failings of the revolving finance system made the VOC's overall position after 1612 precarious. ${ }^{20}$ Until 1610

\footnotetext{
${ }^{19}$ NA 1.11.01.01 Aanwinsten Eerste Afdeling, Inv. No. 626 (1893, 29b), Resolutions of the Heren XVII, March 1612 (30 percent in nutmeg), 31 October 1612 (57.5 percent in cash), August 1613 (42.5 percent), and August/October 1616 (62.5 percent in nutmeg or cash). Schalk (2010) shows that Enkhuizen postponed part of the first payment until 1615.

${ }^{20}$ We estimated annual sales on the basis of the average monthly sales calculated in the Online Appendix Table 8. The reported sales in Figure 3 are an approximation of actual sales revenues because we do not know the distribution of sales within the periods for which the VOC directors reported their commission fees, nor do we know how often rebates (reducing the sales value in exchange for direct payment) were granted to buyers.
} 


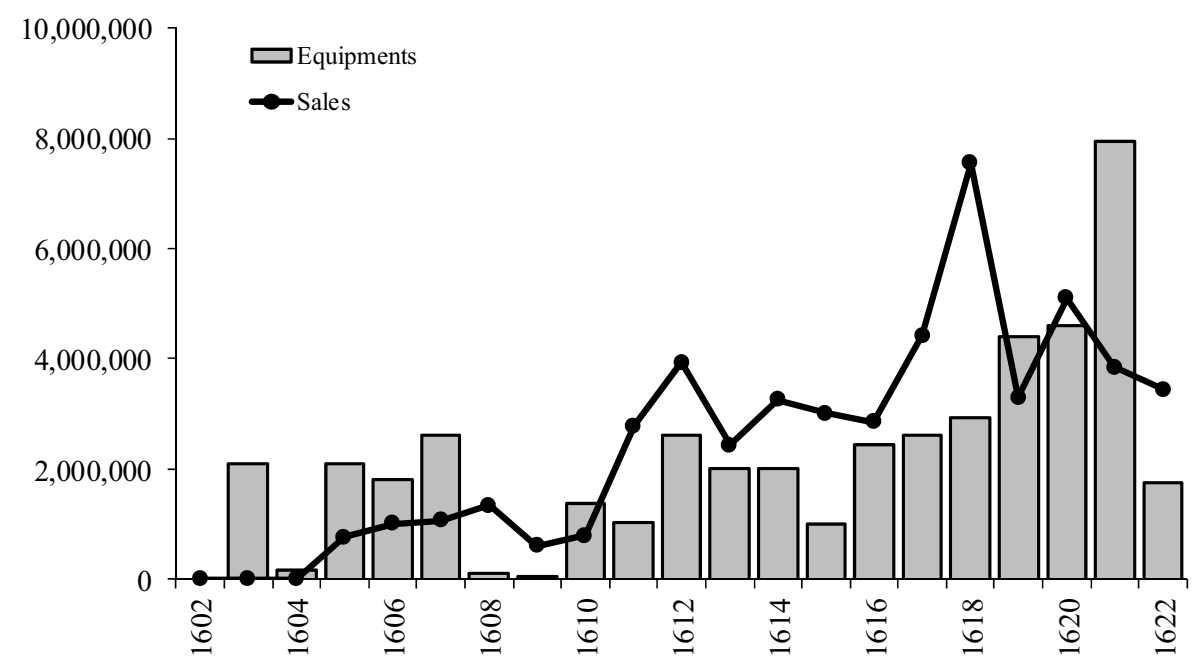

FIGURE 3

ESTIMATED ANNUAL SALES REVENUES AND EXPENDITURE ON THE EQUIPMENT OF VOC FLEETS, 1602-1622

Source: Online Appendix.

the early companies' remaining stocks restricted the volume of VOC sales. Once these had sold out sales picked up to peak at an estimated 4 million guilders in 1612, but up to and including 1616 annual sales averaged still no more than 3 million guilders a year. At first sight this ought to have sufficed for raising the size of fleets sent out, but in fact the company could only invest some 2 million guilders a year and in 1615 even only half that amount, simply because operating costs continued to absorb large sums of money, while dividends due in 1613 and 1616 may have required up to 5 million guilders.

In these circumstances conserving the company's overseas position through collaboration rather than expansion posed an appealing alternative. If the VOC could form a united front against the Iberians with the EIC, for instance, the company could gain military strength and offload some of its costs. The EIC had operated quite successfully during 1609-1612, organizing seven voyages which paid average dividends of 174 percent per voyage (Chaudhuri 1965, p. 209). This rankled in the Republic. Van Oldenbarnevelt, for instance, thought that the British were freeriding on Dutch power and ought to be made to pay their share (Van Ittersum 2006, p. 377). Moreover, in 1613 the EIC followed the VOC's 1602 example and had its shareholders commit their money for a span of eight years, enabling directors to finance 
equipment with retained earnings. The EIC also posed a threat to the VOC's attempt to control the market for spices and thereby prop up prices and revenues. However, talks between British and Dutch representatives in 1613 and again in 1615 ended without reaching any kind of agreement, whether on sales coordination, joint operations, or a possible merger. ${ }^{21}$

Meanwhile, the VOC had been discussing strategy with its newly appointed manager of the Bantam factory and future governor general, Jan Pietersz Coen. Like Matelieff before him, Coen argued in January 1614 that the VOC needed to establish a permanent operational hub if it was to deal effectively with the Spanish aggression and British freeriding on its military efforts. ${ }^{22}$ At that moment the VOC lacked the money even to maintain a steady flow of ships, let alone to increase efforts. Coen accepted this and first wanted the Estates General to step in and send the forces required (Colenbrander 1934, pp. 48-54, 75, 451-74). When the VOC board of directors turned his plan down, Coen fell in with a policy suggested by the Amsterdam Chamber's directors, who preferred to neutralize the EIC's potential threat to European prices by raising the amount of silver sent out and buy up all spices. ${ }^{23}$ In November 1615 the VOC board agreed. Subsequent fleets were to carry more than the usual amount of silver in order to raise the volume of purchases and directors hoped that the resulting sales would also generate the revenues needed to mobilize the forces for Coen to capture his hub. ${ }^{24}$

The sales and investment estimates reported in Figure 3 reflect this policy change. From 1616 the VOC raised silver shipments by a factor of two, resulting in larger return cargoes and a jump in sales from 250,000 guilders per month in 1616 to more than 600,000 guilders by the end of $1618 .{ }^{25}$ Consequently substantially bigger fleets could be sent out; a total of 66 ships left the Republic for Asia between December 1618 and December 1621 at a total cost of almost 17 million guilders. Now Coen could embark on his expansion. In 1619 he captured the Fort Jacatra on Java, renamed it Batavia, and started to build the VOC's operational hub there. Two years later he launched a campaign to

\footnotetext{
${ }^{21}$ Nellen (2007, pp. 173-74); Van Ittersum (2006); Clark (1935); Van Oldenbarnevelt to Caron, 3 May 1613 (Veenendaal 1962, pp. 543-46); Cf. Van Oldenbarnevelt to the Dutch ambassador in London, 7 May 1615 (Veenendaal, 1967, p. 107); See also the report ("verbaal") written by Grotius in May 1613 (Correspondence Hugo Grotius, pp. 627-36).

${ }^{22}$ Compare Cornelis Matelieff's letters to Hugo Grotius, 31 August 1610, and 14 December 1613: Correspondence Hugo Grotius, pp. 71-75, 285-87.

${ }^{23}$ Amsterdam directors to Coen, 28 November 1614 and 15 November 1615; Coen, Bescheiden IV, pp. 294, 333.

${ }^{24}$ Amsterdam directors to Coen, 15 November 1615; Coen Bescheiden IV, p. 332.

${ }^{25}$ On silver shipments, see Bruijn, Gaastra, and Schöffer (1987, vol. I, pp. 226-29).
} 
gain control over the spice trade, which he managed to do by capturing the Moluccas in a storm of violence (Colenbrander 1934, pp. 166-69; 234-46).

At first sight, Coen's bold expansion appears the result of directors finally mastering the revolving finance system simply by raising its volume. A closer look reveals that this was not the case. The VOC was forced to continue juggling resources with spending priorities as before. For instance, our reconstruction of cash flows does show a revenue peak in 1618 , but directors had to use this money for paying a 37.5 percent dividend in 1620 so as to appease shareholders in the run up to the 1622 charter expiry. ${ }^{26}$ Meanwhile annual sales stalled at some 4 million guilders and stocks mounted sharply, while equipment costs continued to rise, peaking at double estimated sales revenues in 1621. Consequently the VOC, instead of escaping the constraints of revolving finance through expansion, was caught in it even more deeply than before, only at a higher level. This forced the directors to test the company's financial boundaries and then to move them.

\section{GROPING TOWARDS LIMITED LIABILITY}

Immediately following the acquisition of permanence and the related restructuring of dividend payments in the second half of 1612, directors needed to secure the company's cash position for 1616, when the final installment of cash dividends fell due. This sum was too large to secure through rebates or other short-term debt. The chambers and Amsterdam in particular never borrowed more than a million guilders in short-term deposits, so the directors had to find an alternative. On March 1, 1613 they insured this liability with an ingenious contract guaranteeing that the revenues from the fleet going out that spring would not fall below 3.2 million guilders (Van Dam 1693-1701 (1977); Van Dillen 1958; Stapel and Den Dooren de Jong 1928). ${ }^{27}$ The insurance policy was a sensible safeguard for the continuity of operations, because the company could reasonably expect considerable benefits from sustained investment (Gelderblom, De Jong, and Jonker 2013).

Though ingenious enough the contract failed to provide the desired cover. Its pay-out conditions were met; in August 1616 sales revenues had not reached the stipulated 3.2 million guilders. But the VOC chose not claim from the insurers, probably because virtually all insurers

\footnotetext{
${ }^{26}$ In June 1619 the Heren XVII resolved to pay a 37.5 percent cash dividend per 1 April 1620: NA1.11.01.01 Aanwinsten Eerste Afdeling, Inv. No. 626 (1893, 29b).

${ }^{27}$ The contract is detailed in Van Dam (1977, vol. 1.1, pp. 207-08); see Gelderblom, De Jong, and Jonker (2013) for an English translation of the policy.
} 
doubled as shareholders, many of whom still had a counterclaim on the company for the 1616 dividend. The insurance conditions had anticipated this by stipulating that payments due under the contract were to be settled in cash and not offset against any other claims between parties, but then if the VOC pressed insurers for payment the company equally had to pay up, and it could not. In 1614 the board, desperate to conserve cash, had postponed dividends due the following year, and in 1616 it converted unpaid dividends into interest bearing loans. ${ }^{28}$ Consequently, the VOC's cash constraints probably prevented it from using the stopgap designed to relieve those very constraints.

This put the board back at square one, having to find ways for financing the overseas expansion. Rebates on spice sales provided insufficient stretch and the Estates General limited its support to about half a million guilders in the form of loans given by the Admiralties. ${ }^{29}$ The Amsterdam Chamber turned to the local money market to raise debt in the form of deposits (Van Dillen 1958, pp. 100-02; Coen Bescheiden IV, pp. 328-29), and from 1615 the others followed suit. ${ }^{30}$ The Enkhuizen Chamber, for example, borrowed up to 250,000 guilders during 1616 and 1617 (Schalk 2010). Zeeland, which had managed to equip its fleets with revolving finance until 1616, had to borrow almost the entire amount for the single ship sent out in $1617 .^{31}$

Such large-scale borrowing required stiffening the corporate structure. The VOC chambers preferred to borrow in Amsterdam because of the low rates there; the Middelburg Chamber, for instance, had to pay two percent more locally. ${ }^{32}$ Even when borrowing through the Amsterdam Chamber the other chambers' directors contracted debt

\footnotetext{
${ }^{28}$ On postponement: NA 1.04.02 VOC Inv. No. 100, 20 September 1614, 10 October 1615. On the payment of interest on dividend claims: NA 1.04.02 VOC, Inv. No. 100, 4-17 August 1616 and fol. 396 (August 1617), fol. 418 (20 October - 4 November 1617). In Enkhuizen dividends were postponed until 1618, so the chamber had to pay interest over the arrears: Schalk (2010, pp. 86-92).

${ }^{29}$ A resolution taken by the Estates General on 14 January 1623 records a debt owed by the VOC to the Admiralties of 498,430 guilders for five ships lent to the company in 1619: NA 1.04.02 VOC, Inv. No. 4643.

${ }^{30} \mathrm{Cf}$. on the growth of the Amsterdam money market after 1609: Gelderblom and Jonker (2004, pp. 663-65, 667-68; 2011, p. 7).

${ }^{31}$ In 1617 the Zeeland Chamber charged 30,092 guilders of interest payments on deposits to the account of the 12th fleet. Taking interest at 6.25 percent yields a debt of more than 480,000 guilders. NA 1.04.02 VOC, Inv. No. 13790, carta 102.

${ }^{32}$ The Zeeland Chamber paid 7 and 7.5 percent on deposits from two of its directors in September 1616. Four months later the Zeeland directors feared deposits could only be had at 8 percent. In December 1617 they expected to pay 7.5 to 8 percent (NA 1.04 .02 VOC, Inv. No. 11340, fol. 29r, 32, 46r, 48r). In June 1617 the Amsterdam Chamber resolved to pay 5 percent on deposits from outsiders and 6 percent on deposits from insiders (presumably, shareholders). On October 9th the target rate was set at 5 to 5.5 percent for all deposits. NA 1.04.02 VOC, Inv. No. 228, resolution 19 June 1617.
} 
personally and, as we have noted, they remained personally liable. This posed a serious check on borrowing the sums which the VOC needed for the planned overseas offensive. Unless backed up by some form of safeguard, directors would not likely shoulder the liabilities asked of them, nor could the other chambers fully exploit the facilities open to the Amsterdam Chamber. Consequently in October and November 1617 the Heren XVII took further steps in centralizing financial policy. First they resolved that henceforth all decisions to borrow would be theirs alone, so chambers needed prior permission to raise any money. To keep a check on this, chambers would henceforth present full details about their financial position at every board meeting. At the same time the board transformed the chambers' debt from a personal liability of the director responsible into a joint liability of all. This was done by having all directors sign a contract guaranteeing their chamber's share in future debt pro rata of that chamber's share in the company capital. Their successors would have to do the same. ${ }^{33}$

The contract shows the extent to which the VOC continued to suffer from the local particularism which had inspired its original decentralized structure. After fifteen years in business together the six chambers still mistrusted each other's financial policies sufficiently to require the signatures of all present and future directors if they were to take on joint liabilities. Moreover, the contract demonstrates that the directors themselves conceived debt as a personal, and not a corporate, liability. Indeed, the Heren XVII apparently did not consider the VOC chambers as corporate bodies in the legal sense, able to conduct business in their own name, or else future directors would not have needed to sign as well. By the same token directors could not make the step towards claiming limited liability for themselves, since there existed no entity to assume full liability in their place. ${ }^{34}$ Consequently they made half a step and assumed joint full liability with the 1617 contract, freeing individual directors from risks which the company as a whole had to bear.

This provided a sufficiently strong basis to increase the VOC's leverage. By May 1620 the six chambers had debts totaling some 5 million guilders, of which 72 percent had been raised by the Amsterdam Chamber, and by March 1623 the sum had risen to over 8 million guilders (Figure 4). Most of that money went into expanding operations,

\footnotetext{
${ }^{33}$ NA 1.04.02 VOC, Inv. No. 100, fol 422-424; cf. Van Dam (1927, vol. 1, p. 233).

${ }^{34}$ In 1618 the Heren XVII discussed, but did not adopt, a draft contract conceived in Zeeland freeing the Middelburg directors from claims issuing from loans contracted by other chambers: NA 1.04.02 VOC Inv.No. 100, fol. 460, September 1618.
} 


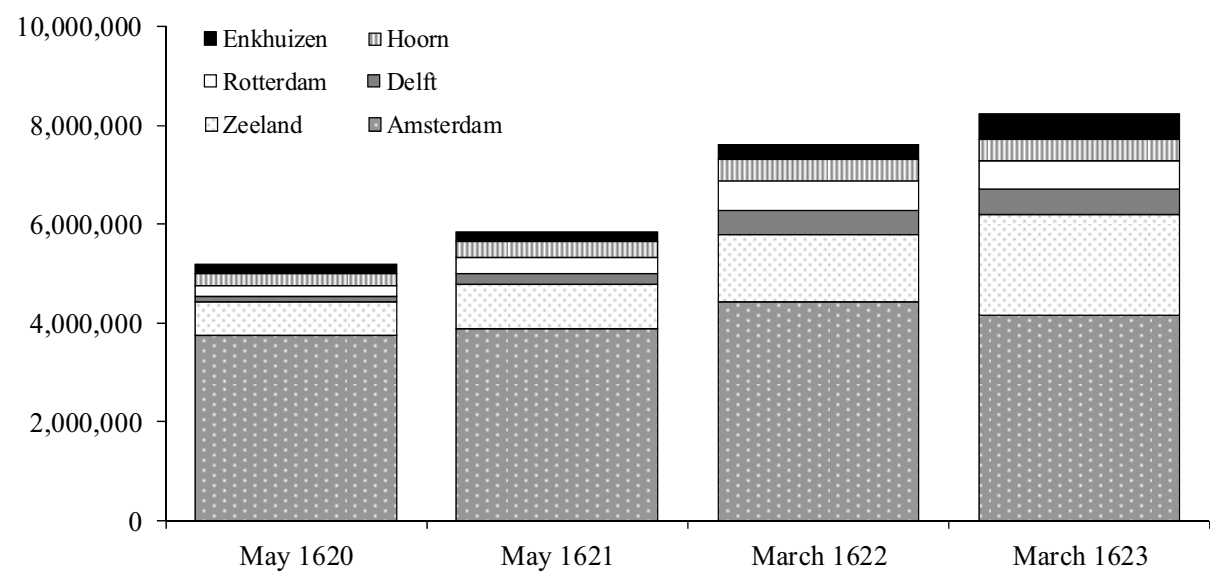

FIGURE 4

DEBT OUTSTANDING OF THE VOC CHAMBERS, 1620-1623

Source: NA 1.04.02 VOC, Inv. No. 100, Resolutions Heren XVII, fol. 550-551, 591, 599, 650.

so when sales slowed down after a record year in 1618 the company found itself in a familiar predicament. Investment continued at a high level without as yet producing sales to match. As a result the VOC carried a debt of 8 million guilders just when full accounts would finally have to be published and a new charter obtained.

It thus became of the utmost importance not just to avoid publication, but also to reject the directors' liability for debt, since the amount could now easily bankrupt them all. The threat of disclosure loomed large indeed. Dissatisfied shareholders conducted a determined and unprecedented pamphlet campaign during 1621-1622, calling on the Estates General not to renew the charter without prior publication of its accounts and demanding strong new clauses to give them more power over company policy. Though the shareholders had the better arguments and the law on their side, the VOC got its way. In December 1622 it obtained a new charter to run from January 1623 for 21 years, having promised to let a committee of shareholders draft accounts for publication. Supported by the Estates of Holland the directors then sabotaged the committee's work. After several years, the committee gave up in frustration (De Jongh 2011).

Formally the new charter changed nothing with regard to the managers' personal liability for debt. Its Clause 47 was identical to the old one. However, the clause had already been undermined by a subtle administrative change, possibly pioneered by the Middelburg Chamber. Surviving bonds show directors guaranteeing debt in the customary 
way with person and goods in December 1621 and January $1622 .{ }^{35}$ However, by late July 1622 the Chamber had started using a substantially different type of bond. This was no longer issued and signed by the bewindhebbers or directors, but by the rekenmeesters or bookkeepers, and it no longer carried the signatories' customary guarantee of person and goods. ${ }^{36}$ In Amsterdam, where the Middelburg bonds were issued, the new bonds appear to have raised investors' concerns about liability. Who carried it: the Middelburg directors, their officials signing the obligations, or the Amsterdam directors placing the debt? To end the confusion the Amsterdam Chamber passed a resolution in October $1623 .^{37}$ The directors rejected creditors' claims that bond signatories were personally liable for the debt which it represented. However, the resolution continued, in order to quell any doubts the text of bonds would be rewritten to explicitly exclude a creditor's recourse to the signatories' person or possessions.

With this final momentous step the directors incorporated limited liability in the VOC's governance structure, one of several unintended consequences of the financial constraints within which the company operated. We do not know exactly what emboldened directors to take this step. Given their ongoing, acrimonious debate with disgruntled shareholders it was not a good moment to ruffle bondholders' feathers, yet they did. Moreover, Middelburg had started issuing the new type of bonds six months before the Estates-General's decision about the charter renewal, so, though the formal rejection of unlimited liability followed the company acquiring quasi permanence, the initial steps towards that position had been taken well before. Presumably the VOC directors felt entitled to do this following the 1621 verdict of the Supreme Court of Holland and Zeeland in an unrelated court case. Originating as far back as 1608 , this case turned on the question whether or not the Amsterdam directors were personally liable for the consequences of fictitious share transfers performed by fraudulent clerks in the chamber's books under their supervision. Overturning verdicts of lower courts, the Supreme Court finally rejected the claims of duped investors, ruling that the company was liable, not its directors. ${ }^{38}$ This suggests legal opinion had

\footnotetext{
${ }^{35}$ Three such bonds in NA 1.04.02 VOC, Inv. No. 7064 (insurance contract), Film No. 4883, one bond from December 1621 and two from January 1622.

${ }^{36}$ One such bond dated 30 July 1622 in NA 1.04.02 VOC, Inv. No. 7064 (insurance contract), Film No. 4883. Two more dated October and November 1622 in the Beinecke Library's possession.

${ }^{37}$ NA 1.04.02 VOC, Inv. No. 228, Revolutions Chamber Amsterdam, 25 October 1623.

${ }^{38}$ NA 3.03.02 Hoge Raad, Inv. No. 714, Film No. 251, sentence 22 December 1621. For the Court of Holland's earlier verdict dated 22 December 1616, see NA 192 Hof van Holland, Inv. Nr. 640.
} 
moved into the direction of according the VOC some form of legal personhood exonerating directors of liability, and this may have inspired them to claim the same for debt.

\section{CONCLUSION}

Our analysis of the VOC's first two decades in operation shows that its corporate form owed less to foresight than to piecemeal engineering to remedy original design flaws surfacing under the strains of the Asian trade. The 1602 chartering of the VOC is generally considered a major breakthrough and the new company did indeed trade on a much bigger scale than its immediate predecessors. But turnover, revenues, return on capital, and return on assets were surprisingly low by comparison with the early ventures. This poor economic performance was a consequence of the policy to build a strong overseas position, both to keep the competition at bay and to acquire a grip on the spice trade. The financial structure underpinning this war-based policy, revolving capital, was too weak to sustain it, however, and locked the VOC in a continuous search to stretch available resources.

Our analysis has also highlighted that, during its initial two decades, the pressure of operational circumstances forced the VOC to remedy serious corporate design flaws: the company's decentralized structure, the unwise reliance on the revolving finance system for fixed investment, the lack of permanence, and the directors' unlimited liability for debt. The pressure level was really a policy consequence: building a strong presence overseas required heavy investment and, above all, a scale of operations which drained revenues and forced directors to choose between keeping large stocks and ruining their own market. Pressure and flaws combined explain successive steps in the VOC's corporate evolution: the harmonization of the chambers' financial policy and its centralization in the hands of the Heren XVII from 1607, the 1612 move towards permanence, the 1617 mutual guarantee for debts contracted by directors, the issuing of bonds from other chambers by Amsterdam, and finally the 1623 rejection of directors' liability for company debt. Consequently, having acquired two key features of the modern corporation, that is to say the split between ownership and management and transferable shares, from the outset, the VOC obtained three more, i.e., a permanent capital, limited liability for directors and by extension legal personhood, stepby-step over a period of some twenty years. Thus the five features did not come as a package, as a coherent logical set. The adoption of one did not automatically lead to the adoption of the others in a process of 
natural legal evolution from simple partnerships via limited partnerships to joint stock limited liability companies. Nor were the features a natural response to the challenges of the intercontinental trade, but the result of friction between financial constraints and operational demands. Since the constraints were determined by outside shareholders and creditors, the driving force behind the VOC's corporate evolution was ultimately its need to raise outside finance (Frentrop 2003).

If we accept this, we have to consider two wider implications. First, the long debate about the exact legal origins of modern corporations misses a vital point. The early modern process of corporate evolution was an adaptive process in which businessmen and lawyers combined concepts from the worlds of government, business, and the law to their needs. But the process derived its logic and driving force from the demands of outside finance, and not at all from a legal system. Tracing the exact antecedents of this or that corporate feature back in Roman law or common law makes sense only if we keep in mind that it was adopted or adapted for economic reasons, not legal ones. To borrow a term from design theory: legal form followed economic function, and not the other way around. The VOC's case does underline, though, one important precondition for processes of institutional change such as this, namely freedom of contract, the freedom to choose the best solution from a range of alternatives. Having this enabled the VOC to swap the insurance contract for something better, the mutual guarantee, and then to improve on that by claiming directors' limited liability. By contrast, the EIC did not possess it, forcing the company to continue relying on the complicated and comparatively expensive insurance contracts until fundamental institutional changes during $1650 \mathrm{~s}$.

Second, our results raise the suggestion to rethink current conceptions about the supposed superiority of Western legal constructs such as the corporation in establishing European dominance. For the corporation was really the Western solution to a specific Western problem, i.e., the need to attract outside finance through the market. If we accept that, this means that societies with alternative ways of mobilizing resources, for instance through kinship or clan ties, did not need to develop similar corporations - but the point is really, to what extent could these alternative ties provide effective substitutes for Western institutions? In our view, this question warrants further research. There is no reason to suppose such ties a priori inferior to market-based formal legal constructs in facilitating key economic functions such as searching, contracting, monitoring, and enforcing. Indeed, they may have been superior, but as long as we keep looking for Western-style corporations we will not find business enterprises organized on the basis of such ties, 
nor will we be able to understand the advantages and disadvantages of alternative ways of organizing business compared to Western solutions. In short, we need to retrain our sights and the VOC example suggests that a good way to start is to examine the logic of a given concern's financial structure.

\section{REFERENCES}

Blussé, L., and G. D. Winius. "The Origin and Rhythm of Dutch Aggression Against the Estado da India, 1601-1661." In Indo-Portuguese History: Old Issue, New Questions, edited by T. R. da Souza, 73-83. New Delhi, 1986.

Bruijn, Jaap R., Femme S. Gaastra, and Ivo Schöffer. Dutch-Asiatic Shipping in the 17th and 18th centuries, 3 volumes. The Hague: Nijhoff, 1979-1987.

Chaudhuri, K. N. The English East India Company: The Study of an Early Joint Stock Company, 1600-1640. London: Cass, 1965.

Clark, G. N. "Grotius's East India Mission to England." Transactions of the Grotius Society 20 (1935): 45-84.

Colenbrander, Herman Theodoor. Jan Pietersz. Coen, levensbeschrijving. The Hague: Nijhoff, 1934.

Colenbrander, Herman Theodoor, and W. Ph. Coolhaas, eds. Jan Pietersz. Coen, bescheiden omtrent zijn bedrijf in Indië, 7 volumes. The Hague: Nijhoff, 1919-1952.

Dari-Mattiacci, Giuseppe, Gelderblom, Oscar, Jonker, Joost and Enrico C. Perotti. "The Emergence of the Corporate Form," 2013. Available online at SSRN: http://ssrn.com/abstract=2223905 or http://dx.doi.org/10.2139/ssrn.2223905.

De Heer, Cornelis. Bijdrage tot de financiëele geschiedenis der Oost-Indische Compagnie. Rotterdam: Carpa, 1929.

Den Heijer, Henk. De geoctrooieerde compagnie. De VOC en WIC als voorlopers van de naamloze vennootschap. Deventer: Kluwer, 2005.

De Jong, Michiel. 'Staat van oorlog.' Wapenbedrijf en militaire hervorming in de Republiek der Verenigde Nederlanden, 1585-1621. Hilversum: Verloren, 2005.

De Jongh, J. M. "Shareholder Activists avant la lettre, the "Complaining Participants" in the Dutch East India Company, 1622-1625." In Origins of Shareholder Advocacy, edited by Jonathan G. S. Koppell, 61-88. New York: Palgrave Macmillan, 2011.

De Korte, J. P. De jaarlijkse financiële verantwoording in de Verenigde Oostindische Compagnie. The Hague: Nijhoff, 1984.

De Vries, Jan. "Connecting Europe and Asia: A Quantitative Analysis of the Cape-Route Trade, 1497-1795." In Global Connections and Monetary History, 1470-1800, edited by Dennis O. Flynn et al., 35-105. Aldershot: Ashgate, 2003.

Diamond, Douglas W. "Debt Maturity Structure and Liquidity Risk." The Quarterly Journal of Economics 106 no. 3 (1991): 709-737.

Du Fresne de Francheville, Joseph. Histoire de la Compagnie des Indes avec les titres de ses concessions \& privileges. Paris: De Bure l'aîné, 1738.

Enthoven, Victor. Zeeland en de opkomst van de Republiek. Handel en strijd in de Scheldedelta c. 1550-1621. Leiden: Rijksuniversiteit, 1996.

Frentrop, Paul. A History of Corporate Governance, 1602-2002. Brussels: Deminor, 2003.

Gaastra, Femme. De geschiedenis van de VOC. Zutphen: Walburg Pers, 2007. 
Gelderblom, Oscar. "The Governance of Early Modern Trade: The Case of Hans Thijs, 1556-1611.” Enterprise \& Society 4, no. 4 (2003): 606-39.

Gelderblom, Oscar, Abe de Jong, and Joost Jonker. "An Admiralty for Asia. Isaac le Maire and Conflicting Conceptions About the Corporate Governance of the VOC." In The Origins of Shareholder Advocacy, edited by Jonathan G. S. Koppell, 29-60. New York: Palgrave Macmillan, 2011.

"The VOC Insurance Contract of 1613." Working Paper 2013 Utrecht University, available online at http://vkc.library.uu.nl/vkc/seh/research/Pages/WorkingPapers.aspx.

Gelderblom, Oscar, and Joost Jonker, "Completing a Financial Revolution: The Finance of the Dutch East India Trade and the Rise of the Amsterdam Capital Market, 1595-1612." The Journal of Economic History 64, no. 3 (2004): 641-72.

Hansmann, Henry, and Reinier Kraakman. "The Essential Role of Organizational Law." The Yale Law Journal 110 (2000): 387-440.

. "What is Corporate Law?" In Reinier R. Kraakman, Paul Davies, Henry Hansmann, Gerard Hertig, Klaus J. Hopt, Hideki Kanda, and Edward B. Rock. The Anatomy of Corporate Law; A Comparative and Functional Approach, 1-19. Oxford: Oxford University Press, 2004.

Hansmann, Henry, Reinier H. Kraakman, and Richard C. Squire. "Law and the Rise of the Firm." Yale Law \& Economics Research Paper No. 326, 2006. Available online at SSRN, http://ssrn.com/abstract $=873507$ or http://dx.doi.org/10.2139/ssrn.873507.

Harris, Ron. Industrializing English Law: Entrepreneurship and Business Organization, 1720-1844. Cambridge: Cambridge University Press, 2000.

. "Law, Finance, and the First Corporations." In Global Perspectives on the Rule of Law edited by James J. Heckman, Robert L. Nelson, and L. Cabatingan, 145-72. Abingdon: Routledge-Cavendish, 2010.

Kuran, Timur. The Long Divergence: How Islamic Law Held Back the Middle East. Princeton, NJ: Princeton University Press, 2010a.

. "The Scale of Entrepreneurship in Middle Eastern History: Inhibitive Roles of Islamic Institutions." In Entrepreneurs and Entrepreneurship in Economic History, edited by William Baumol et al., 62-87. Princeton, NJ: Princeton University Press, $2010 \mathrm{~b}$.

Lesger, Clé. The Rise of the Amsterdam Market and Information Exchange: Merchants, Commercial Expansion, and Change in the Spatial Economy of the Low Countries, c. 1550-1630. Ashgate: Burlington, Vt., 2006.

Molhuysen, P. C., et al. The Correspondence of Hugo Grotius, available online at http://grotius.huygens.knaw.nl/years, 1928-2001.

Murphy, Henry C. Henry Hudson in Holland: An Inquiry into the Origin and Objects of the Voyage Which Led to the Discovery of the Hudson River. New York: Cosimo, 1972.

Nellen, Henk. Hugo de Groot. Een leven in strijd om de vrede, 1583-1645. Amsterdam: Balans, 2007.

Parthesius, Robert. Dutch Ships in Tropical Waters: The Development of the Dutch East India Company (VOC) Shipping Network in Asia, 1595-1660. Amsterdam: Amsterdam University Press, 2010.

Rietbergen, P. J. A. N. (Peter). De Eerste Landvoogd Pieter Both (1568-1615). Gouverneur-generaal van Nederlands-Indië (1609-1614). 2 volumes. Zutphen: De Walburg Pers, 1987. 
Sainsbury, E. B. A Calendar of the Court Minutes, etc. of the East India Company 1635-1679, 11 vols. Oxford: Oxford University Press, 1907-1938.

Sainsbury, W. N. Calendar of State Papers, Colonial Series, East Indies, China, Japan, and Persia. London, 1892; reprinted by: Kraus (Vaduz 1964-1978).

Schalk, Ruben, "Financing the Dutch Golden Age: The Market for Credit in Enkhuizen, 1580-1700." Unpublished MA Thesis, Utrecht University, 2010.

Scott, W. R. The Constitution and Finance of English, Scottish, and Irish Joint Stock Companies to 1720. 3 volumes. 1912. Reprint Gloucester Mass.: P. Smith 1968.

Shareholder Rights at 400, Commemorating Isaac Le maire and the First Recorded Expression of Investor Advocacy. APG: s.1. 2009.

Stapel, F. W., and E. L. G. den Dooren de Jong. "Bijdragen tot de geschiedenis der zeeverzekering. I. De zeeverzekering der Vereenigde Oostindische Compagnie." Het Verzekeringsarchief IX (1928): 81-108.

Steensgaard, Niels. Carracks, Caravans, and Companies: The Structural Crisis in the European-Asian Trade in the Early Seventeenth Century. Odense: Studentlitteratur, 1973.

. "The Dutch East India Company as an Institutional Innovation" In Dutch Capitalism and World Capitalism, edited by Maurice Aymard, 235-57. Cambridge: Cambridge University Press, 1982.

Van Brakel, Simon. De Hollandsche handelscompagnieën der zeventiende eeuw, hun ontstaan-hunne inrichting. The Hague: Nijhoff, 1908.

Van Dam, Pieter. Beschryvinge van de Oostindische Compagnie, Volume I, edited by F.W. Stapel. The Hague: Nijhoff, 1927.

Van Dillen, J. G. "Isaac le Maire en de handel in actiën der Oost-Indische Compagnie." Economisch-historisch jaarboek 16 (1930): 1-165.

. Het oudste aandeelhoudersregister van de Kamer Amsterdam der OostIndische Compagnie. The Hague: Nijhoff, 1958.

Van der Chys, J. A. De stichting der Vereenigde O.I. Compagnie. Leiden: Engels, 1854.

Van der Heijden, Egidius J. J. De ontwikkeling van de naamlooze vennootschap in Nederland vóór de codificatie. Amsterdam: Van der Vecht, 1908.

Van Ittersum, Martine Julia. Profit and Principle: Hugo Grotius, Natural Rights Theories, and the Rise of Dutch Power in the East Indies (1595-1615). Boston/Leiden: Brill, 2006.

Van Rees, O. Geschiedenis der koloniale politiek van de Republiek der Vereenigde Nederlanden. Utrecht: Kemink, 1686.

Veenendaal, A. J. Johan van Oldenbarnevelt. Bescheiden betreffende zijn staatkundig beleid en zijn familie. Volume 2, 1602-1613. The Hague: Nijhoff, 1962.

. Johan van Oldenbarnevelt. Bescheiden betreffende zijn staatkundig beleid en zijn familie. Volume 3, 1614-1620. The Hague: Nijhoff, 1967.

Warnsinck, J. C. M. De Reis om de Wereld van Joris van Spilbergen, 1614-1617. The Hague: Martinus Nijhoff, 1943.

Witteveen, Menno. Antonio van Diemen. De opkomst van de VOC in Azië. Amsterdam: Pallas Publicaties, 2011. 